\title{
PENERAPAN METODE PQR4 UNTUK MENINGKATKAN PEMAHAMAN MEMBACA PADA SISWA KELAS IV SDN PENGAMPON II KEC. LEMAHWUNGKUK KOTA CIREBON
}

\author{
Oleh \\ Syibli Maufur* \& Abdul Sholeh, M. Pd* \\ *Dosen Jurusan PGMI FITK IAIN Syekh Nurjati Cirebon
}

\begin{abstract}
ABSTRAK
Bahasa Indonesia merupakan mata pelajaran wajib di SD / MI yang didalamnya terdapat asfek keterampilan membaca yang memiliki peran sentral dalam perkembangan intelektual, sosial, dan emosional dan penunjang keberhasilan dalam mempelajari semua bidang studi namun ditemukan permasalahan yaitu rendahnya kemampuan pemahaman membaca yakni siswa kesulitan menentukan kalimat utama, siswa kesulitan dalam membuat teks ringkasan dengan kalimat yang runtut, dan siswa kesulitan dalam menjelaskan isi teks secara tertulis dengan kalimat sendiri secara runtut. Sebagai solusi atas kondisi tersebut diperlukan suatu metode pembelajaran yang lebih bermakna bagi siswa untuk meningkatkan kemampuan membaca pemahaman diantaranya melalui metode PQR4 yaitu Preview, Question Read, Reflect Recite dan Review. Penelitian tindakan kelas (Classroom Action Research) ini dalam upaya memperbaiki dan meningkatkan praktik pembelajaran dengan desain siklus spiral model Kemmis. Hasil temuan penelitian diperoleh nilai rata-rata siklus I yaitu 73,80, Siklus II yaitu 77,60, dan siklus III yaitu 83,40. Dengan demikian metode PQR4 dapat meningkatkan kemampuan membaca pemahaman.
\end{abstract}

Kata kunci: Metode PQR4, membaca pemahaman

\section{A. Pendahuluan}

Bahasa Indonesia diikrarkan sebagai bahasa persatuan sejak peristiwa Kongres Sumpah Pemuda. Hal tersebut memiliki implikasi diantaranya yaitu Undang-Undang Sistem Pendidikan Nasional Pasal 33 menyatakan bahwa : "Bahasa Indonesia sebagai Bahasa Negara menjadi bahasa pengantar dalam pendidikan nasional".

Sekolah Dasar/ Madrasah Ibtidaiyah merupakan lembaga pendidikan formal yang dalam pembelajarannya terdapat mata pelajaran wajib yaitu 
Bahasa. Hal ini di dasari oleh PP nomor 32 Tahun 2013 Tentang Perubahan Atas PP No. 19 Tahun 2013 Pasal 77I menyatakan bahwa: "Struktur Kurikulum SD/MI, SDLB atau bentuk lain yang sederajat terdiri atas muatan: a. pendidikan agama; b.pendidikan kewarganegaraan; c. bahasa, ...”.

Bahasa memiliki peran sentral dalam perkembangan intelektual, sosial, dan emosional peserta didik dan merupakan penunjang keberhasilan dalam mempelajari semua bidang studi. BSNP (2007: 6) mengungkapkan bahwa: Ruang lingkup mata pelajaran Bahasa Indonesia mencakup komponen kemampuan berbahasa dan kemampuan bersastra yang meliputi: 1 . Mendengarkan; 2. Berbicara; 3. Membaca; 4. Menulis. Pada akhir pendidikan di SD/MI, peserta didik telah membaca sekurang-kurangnya sembilan buku sastra dan nonsastra.

Membaca merupakan salah satu dari empat bentuk keterampilan berbahasa yang sangat penting untuk dikuasai. Membaca dianggap penting karena menurut Rahim ( 2005:1) "Masyarakat yang gemar membaca akan memperoleh pengetahuan dan wawasan baru yang akan semakin meningkatkan kecerdasan sehingga lebih mampu menjawab tantangan hidup pada masa masa mendatang". Dengan demikian, begitu pentingnya keterampilan membaca untuk dikuasai, karena dengan membaca pengetahuan dapat bertambah.

Menurut Tarigan (1990: 10) :

Membaca merupakan kemampuan yang kompleks. Membaca bukanlah kegiatan kegiatan memandang lambang-lambang tertulis semata-mata. Bermacam-macam kemampuan dikerahkan oleh seorang pembaca agar dia mampu memahami materi yang dibacanya.... Membaca merupakan interaksi antara pembaca dan penulis. Interaksi tersebut tidak langsung, namun bersifat komunikatif. Komunikasi antara pembaca dan penulis akan makin baik jika pembaca mempunyai kemampuan yang lebih baik...

Membaca bukanlah kegiatan pasif. Terjadinya interaksi antara pembaca dan yang ditulis merupakan hal yang akan berpengaruh pada pembaca, sehingga pembaca dapat memaknai bacaannya dengan melakukan kegiatan yang nyata yang disebutkan dalam bacaan. Kegiatan membaca akan lebih baik jika pembaca mempunyai kemampuan dalam membaca. Kemampuan membaca 
tiap orang berbeda-beda tergantung dari pengalamannya. Kemampuan membaca sama halnya dengan kemampuan berbahasa yang menurut Akhadiah, (1992/1993: 2) "Kemampuan itu tidak dibawa sejak lahir dan dikuasainya sendiri melainkan harus dipelajari". Dari pernyataan tersebut dapat disimpulkan bahwa kemampuan membaca seseorang tergantung pada penguasaan keterampilan membaca yang telah dipelajarinya. Semakin baik keterampilan membaca yang dipelajarinya, maka seharusnya kemampuan membacanya pun semakin baik.

Keterampilan membaca di SD/MI dibedakan atas dua tahap yaitu keterampilan membaca di kelas rendah dan keterampilan membaca di kelas tinggi. Keterampilan membaca di kelas rendah untuk kelas 1 dan 2 yang disebut membaca permulaan. Sedangkan keterampilan membaca untuk kelas tinggi yaitu kelas 3 sampai 6 disebut membaca lanjut atau membaca pemahaman. Tingkatan membaca pemahaman lebih tinggi daripada membaca permulaan. Tujuan dari membaca pemahaman atau membaca lanjut menurut Akhadiah, (1992/1993:37) “Agar siswa mampu memahami, menafsirkan serta menghayati isi bacaan”. Pelajaran membaca pemahaman di kelas tinggi diharapkan agar siswa tidak hanya dapat membaca dengan baik dalam artian tepat lafal dan intonasinya, namun siswa dapat memahami isi dari bacaan.

Pada pembelajaran Bahasa Indonesia di kelas IV SDN Pengampon II Kec. Lemhawungkuk Kota Cirebon, ditemukan permasalahan yaitu siswa kesulitan dalam proses pembelajaran membaca pemahaman. Permasalahan ini terjadi karena siswa tidak paham isi bacaan. Keterampilan siswa dalam membaca pemahaman masih kurang, sehingga siswa tidak bisa menentukan gagasan utama dari bacaan, kurang mampu membuat ringkasan serta siswa tidak dapat menceritakan kembali bacaan dengan bahasanya sendiri. Kondisi tersebut mengakibatkan rendahnya nilai rata-rata kemampuan memahami bacaan yaitu 63,80 .

Permasalahan tersebut memerlukan suatu upaya untuk pemecahannya melalui metode pembelajaran yang mampu meningkatkan kemampuan membaca pemahaman siswa. Karena menurut pendapat Djuanda, (2008:117). 
"Melalui pengajaran membaca pemahaman yang dirancang dan dilaksanakan dengan baik, siswa tidak saja memperoleh peningkatan kemampuan bahasa, tetapi juga peningkatan bernalar, kreativitas, dan penghayatan terhadap nilainilai moral".

Bedasarkan pernyataan tersebut selain mengungkapkan besarnya manfaat pengajaran membaca pemahaman, dan untuk meningkatkan kemampuan berbahasa diperlukan juga rancangan pembelajaran yang tepat, salah satu metode yang dapat digunakan untuk pembelajaran pemahaman membaca yaitu metode PQR4. Merujuk pada pendapat Trianto, (2007:133 ) "Metode PQR4 digunakan untuk membantu siswa mengingat apa yang dibaca”. Metode PQR4 yang mempunyai langkah-langkah pembelajaran yang terdiri dari Preview (membaca selintas), Question (Tanya-jawab), Read (membaca intensif), Reflect (memahami), Recite (mengingat), dan Review (mengulang), merupakan suatu metode membaca yang tersusun secara sistematis untuk meningkatkan pemahaman bacaan. Langkah-langkah tersebut akan memberikan arahan bagi siswa bagaimana dapat memahami suatubacaan dan menemukan gagasan utama bacaan dengan mengikuti kegiatan dalam metode PQR4 ini. menurut Soedarso (2006:64)"Menemukan ide pokok suatu paragraf atau bacaan adalah kunci untuk mengerti apa yang kita baca".

Berdasarkan uraian tersebut, maka dapat dirumuskan permasalahan sebagai berikut: (1) Apakah metode PQR4 dapat meningkatkan membaca pemahaman pada siswa Kelas IV SDN Pengampon II? (2) Bagaimanakah penerapan metode PQR4 di Kelas IV SDN Pengampon II tentang membaca pemahaman?

\section{LANDASAN TEORI}

\section{A. Membaca}

\section{Pengertian Membaca}

Kamus Besar Bahasa Indonesia (2005:83) menjelasakan bahwa: "membaca adalah melihat serta memahami isi dari apa yang tertulis dengan menglisankan atau hanya di hati." Dari arti tersebut memberikan petunjuk bahwa dalam membaca melibatkan asfek fisik seperti mata. Membaca menurut 
Djuanda (2008:171)“ Suatu proses yang dilakukan serta dipergunkan pembaca untuk memperoleh pesan yang hendak disampaikan oleh penulis melalui media kata-kata/ bahasa tulis.” Menurut Rahim, (2005: 2)“ Membaca pada hakikatnya adalah sesuatu yang rumit yang melibatkan banyak hal, tidak tidak hanya sekadar melafalkan tulisan, tetapi juga melibatkan aktivitas visual, berpikir, psikolinguistik dan metakognitif'. Berdasarkan ketiga penulis di atas membaca pada dasarnya adalah suatu proses. Dalam hal ini membaca adalah proses untuk memperoleh suatu pesan sebagai tujuan utamanya. Menurut Akhadiah dkk. (1992/1993: 22) "Membaca merupakan suatu kesatuan kegiatan yang terpadu yang mencakup beberapa kegiatan seperti mengenali huruf dan katakata, menghubungkan dengan bunyi serta maknanya, serta menarik kesimpulan menjadi maksud bacaan".

Menurut beberapa pendapat di atas, bahwa pada hakekatnya membaca adalah suatu proses kegiatan mengenal huruf yang melibatkan aktivitas visual, psikolinguistik, dan metakognitif untuk menterjemahkan kode-kode dalam bentuk tulisan sehingga dapat ditarik kesimpulan dari maksud yang dituangkan oleh penulis dalam bacaan tersebut.

Sebagai proses visual membaca merupakan proses menterjemahkan simbol tulis (huruf) ke dalam kata-kata lisan, sebagai suatu proses berpikir, membaca mencakup aktivitas pengenalan kata, pemahaman literal, interpretasi, membaca kritis, dan pemahaman kreatif. Dari segi linguistik membaca adalah suatu proses penggantian kembali (recording) dan pembacaan sandi atau (decoding).

\section{Tujuan Membaca}

Tujuan membaca menurut Rahim (2005:11-12) adalah

1)Kesenangan; 2) Menyempurnakan membaca nyaring; 3) Menggunakan strategi tertentu; 4) Memperbaharui pengetahuannya tentang suatu topik; 5) Mengaitkan informasi baru deangan informasi yang telah diketahuinya; 6) Memperoleh informasi untuk laporan lisan dan tulisan; 7) Mengkonfirmasikan atau menolak prediksi; 8) Menampilkan suatu eksperimen atau mengaplikasikan informasi yang diperoleh dari susatu teks dalam beberapa cara lain dan mempelajari struktur tentang teks;9) Menjawab pertanyaan-pertanyaan yang spesifik; 
Sedangkan tujuan membaca menurut Supriyadi (1992: 121) adalah"Untuk mengisi waktu luang atau hiburan, untuk studi (secara akademi), untuk mencari informasi, untuk memperkaya pembendaharaan kosa kata, dan lain-lain”. Secara umum menurut Akhadiah (1992/1993: 115-116)adalah: 1. Untuk mendapat infomasi. 2. Meningkatkan citra diri. 3. Melepaskan diri dari kenyataan. 4. Membaca untuk tujuan rekretif. 5. Mencari nilai-nilai keindahan atau pengalaman astetis.

\section{Komponen Kegiatan Membaca}

Kegiatan membaca menurut Rahim (2005:12). "Proses dan produk". Proses membaca mencakup sembilan aspek untuk menghasilkan produk. yaitu sensori, perseptual, urutan, pengalaman, pikiran, pembelajaran, asosiasi, sikap, dan gagasan”. Proses membaca dimulai dengan sensori visual yang diperoleh melalui pengungkapan simbol-simbol grafis melalui indra penglihatan. Anakanak belajar membedakan secara visual di antara simbol-simbol grafis (huruf atau kata) yang digunakan untuk mempresentasikan bahasa lisan. Kegiatan perseptual, yaitu aktivitas mengenal suatu kata sampai pada makna berdasarkan pengalaman yang lalu. Pengalaman langsung dan pengalaman tidak langsung akan meningkatkan perkembangan konseptual anak,namun pengalaman langsung lebih efektif dari pada pemgalaman tidak langsung”.

\section{Faktor-faktor yang Mempengaruhi Kemampuan Membaca}

Faktor-faktor yang mempengaruhi kemampuan membaca yaitu fisiologis, intelektual, lingkungan dan psikologis. Menurut Rahim (2005: 16-19). "Faktor fisiologis mencakup kesehatan fisik, pertimbangan neurologis, dan jenis kelamin”. Faktor Intelektual, Faktor Lingkungan Faktor lingkungan mencakup (1) latar belakang dan pengalaman siswa di rumah, dan (2) sosial ekonomi keluarga siswa". Pendapat yang sama dikemukakan Akhadiah (1992/1993: 26) "Pembicara orang tua serta anggota keluarga lainnya di rumah juga akan mempengaruhi kemampuan membaca anak." Adapun faktor psikologis mencakup (1) motivasi, (2) minat, dan (3) kematangan social, emosi dan penyesuaian diri." Menurut Akhadiah (1992/1993). "Bahan bacaan akan mempengaruhi sessorang dalam minat maupun kemampuan memahaminya. 
Bahan bacaan yang terlalu sulit untuk seseorang akan mematahkan selera untuk membacanya". Faktor yang ketiga adalah kematangan sosial, emosi dan penyesuaian diri.

\section{Pembelajaran Membaca Pemahaman}

\section{a. Definisi Membaca Pemahaman}

Membaca pemahaman dapat pula diartikan sebagai serangkaian proses yang dilakukan pembaca untuk menemukan informasi dan memahami informasi yang terkandung dalam sebuah teks bacaan .kegiatan ini merupakan perpaduan antara kemampuan visual sangat berguna untuk menelusuri symbolsymbol tertulis dan kemampuan kognitif berguna untuk memberikan tingkat pemahaman atas makna yang terkandung symbol-simbol tersebut . Kemampuan membaca pemahaman berbeda dengan kemampuan membaca permulaan.dalam membaca pemahaman terdapat beberapa indikasi pemahaman yang perlu diperhatikan guna menentukan ketercapaian tujuan pembelajaran.

Beberapa indikasi membaca pemahaman yang harus tercapai yaitu: (1) Melakukan pembaca memberikan respon fisik terhadap perintah membaca; (2) Memilih, pembaca memilih alternatif bukti pemahaman baik secara lisan atau tulisan; (3) Mengalihkan, pembaca mampu menyampaikan secara lisan apa yang telah dibacanya; (4) Menjawab, pembaca mampu menjawab pertanyaan tentang isi bacaan; (5) Mempertimbangkan, pembaca mampu menggarisbawahi atau mencatat pesan-pesan penting yang terkandung dalam bacaan; (6) Memperluas, pembaca mampu memperluas bacaan atau minimalnya mampu menyusun bagian akhir cerita [khusus untuk bacaan fiksi].; (7) Menduplikasi, pembaca mampu membuat wacana serupa dengan wacana yang dibacanya (menulis cerita berdasarkan versi pembaca) ; (8) Modeling pembaca mampu memainperankan cerita yang dibacanya; (9) Mengubah,pembaca mampu mengubah wacana ke dalam bentuk wacana lain yang mengindikasikan adanya pemrosesan informasi.(Brown, Abidin, 2010 : 128)

\section{b. Prinsip - Prinsip Pembelajaran Membaca Pemahaman}


Brown, (Abidin, 2010 : 129) mengemukakan bahwa untuk mencapai keberhasilan dalam pembelajaran membaca pemahaman, perlu diperhatikan beberapa prinsip dasar mendasain pembelajaran membaca pemahaman yaitu: 1 . Tidak mengabaikan pentingnya merumuskan tujuan pembelajaran membaca secara spesifik; 2. Gunakan teknik/srategi pembelajaran membaca yang mampu membangun motivasi; 3. Perhatikan keaslian (kesesuain dengan konteks siswa) dan keterbacaan wacana yang dipilih; 4. Terapkan metode membaca yang paling tepat; 5. Terapkan model baca interaktif; 6. Laksanakanlah prosedur pembelajaran membaca dengan membaginya ke dalam tiga tahapan yakni tahap prabaca, tahap membaca,dan tahap pascabaca; 7. Gunakan prinsip srategi membaca pemahaman meliputi: a. Identifikasi tujuan baca secara jelas dan nyata; b. Gunakan teknik membaca dalam hati yang efesien; c. Gunakan srategi membaca skimming untuk menemukan ide pokok bacaan; d. Gunakan srategi membaca scanning untuk menemukan informasi khusus; e. Gunakan peta konsep untuk mempermudah pemahaman bacaan; f. Gunakan tebakan untuk mendefinisikan kata yang belum diketahui maknanya; g. Analisislah lebih lanjut kata/kosakata yang belum dipahami; h. Bedakanlah antara makna literal dan makna implikatif; i. Tandai penanda wacana yang menandakan keterhubungan antara ide satu dengan ide lainnya; 8. Kembangkanlah aspekaspek evaluasi; 9. Lakunlah penilaian baik penilain proses maupun penilaian kemampuan membaca.

\section{Prosedur Umum Pembelajaran Membaca Pemahaman}

Prosedur pembelajaran membaca pemahaman harus dilaksanakan dalam tiga tahapan yaitu; tahap prabaca, tahap membaca ,dan tahap pascabaca. Hadley ( Abidin,2010: 133). 1. Tahap prabaca, yakni tahapan yang dilakukan siswa sebelum membaca; 2. Tahap baca, yakni tahapan inti kegiatan pembelajaran membaca yakni Tahap membaca skimming dan scanning dengan tujuan yaitu: (1) menemukan inti sari bacaan, (2) mengidentifikasi ide utama dan kalimat utama,(3) memilih uraian terpenting yang terkandung dalam bacaan, (4) mencocokan subjudul dengan paragraph isi, (5) mengisi format isi bacaan dengan kata-kata kunci,dan (6) buatlah tanggapan umum atas isi 
bacaan. Tahap membaca intensif teks. Tahap pemahaman; 3. Tahap Pascabaca, yakni tahap untuk membuktikan pemahamannya atas hasil kegiatan baca yang dilakukannya.Tahapan ini dapat dilakukan melalui kegiatan integrasi membaca dengan keterampilan berbahas yang lain,misalnya menulis rangkuman,membuat versi lain bacaan, dan menceritakan kembali isi bacaan secara lisan.

\section{B. Metode PQR4}

\section{a. Pengertian Metode PQ4R}

PQR4 merupakan kependekan dari Preview, Question, Read, Reflect, Recite, dan Review. Yang dalam bahasa Indonesia berarti membaca selintas, tanya, baca, mengingat, mengatakan dan mengulang. Metode PQR4 merupakan salah satu bagian dari strategi elaborasi yang menurut Trianto (2007: 146) "Strategi elaborasi adalah proses penambahan perincian sehingga informasi baru akan menjadi lebih bermakna, oleh karena itu membuat pengkodean lebih mudah dan lebih memberikan kepastian." Metode PQR4 adalah suatu metode membaca yang digunakan untuk membantu siswa mengingat dan memahami apa yang dibacanya melalui enam kegiatan yakni membaca selintas, membuat pertanyaan dan jawaban, membaca intensif, menghubungkan dengan pengetahuan yang dimiliki, mengingat isi bacaan, dan diakhiri dengan peninjauan ulang terhadap hasil kegiatan membaca.

\section{b. Tujuan Metode PQR4}

Menurut Trianto (2007: 146) "Metode PQR4 digunakan untuk membantu siswa mengingat apa yang mereka baca, dan dapat membantu proses belajar mengajar di kelas yang dilaksanakan dengan kegiatan membaca buku". Dengan metode ini siswa diarahkan untuk dapat mengingat dan memahami bacaan, sehingga kegiatan membaca siswa akan lebih bermakna karena ada pengetahuan yang didapat dari hasil kegiatan membacanya.

Tujuan Metode PQR4 menurut Trianto (2007: 144) yaitu "mengajarkan siswa untuk belajar atas kemauan sendiri”. Menurut Trianto (2007: 146) "Strategi ini membantu pemindahan informasi baru dari jangka pendek ke jangka panjang, melalui penciptaa gabungan dan hubungan antara informasi 
baru dan apa yang telah diketahui." Para ahli telah menunjukan bahwa metode PQR4 dapat meningkatkan keterampilan membaca siswa dengan mengingat dan memahami konsep suatu bacaan.Pembelajaran membaca dengan menggunakan metode PQR4 mengikuti langkah-langkah pada metode PQR4 pada saat membaca siswa dapat belajar secara mandiri dalam memahami bacaan.

\section{c. Langkah-langkah Metode PQR4}

1) Preview yakni siswa membaca secara sekilas dengan cepat sebelum memulai membaca dengan tujuan mencari ide pokok. Kegiatan ini didapatkan sedikit gambaran awal dari isi teks bacaan, yang dapat berupa tema dari bacaan. Dengan demikian hal ini akan memudahkan siswa membuka skematanya.

2) Question yakni mendalami topik dan judul dengan mengajukan pertanyaan yang jawabannya dapat ditemukan dalam bacaan tersebut, kemudian mencoba menjawabnya sendiri. Pada umumnya setelah kegiatan membaca hal yang sering dilakukan adalah menjawab pertanyaan. Dalam metode ini sedikit perbedaan, siswa disuruh untuk membuat pertanyaan sendiri dengan menggunakan kata tanya apa, siapa, mengapa dan bagaimana. Hal ini bertujuan untuk meningkatkan pemahaman siswa pada isi teks bacaan. Karena menurut Trianto (2007: 148) "Pengalaman telah menunjukan bahwa apabila seseorang membaca untuk sejumlah pertanyaan, maka akan membuat dia membaca hati-hati dan seksama serta akan dapat membantu siswa mengingat apa yang dibaca dengan baik." Dengan kegiatan ini cara membaca kita menjadi lebih aktif lebih mudah menangkap gagasan yang ada daripada kalau hanya membaca asal membaca.

3) Read yakni membaca intensif bacaan, dengan cara pikiran siswa harus memberikan reaksi terhadap apa yang dibacanya. Subagyo (2005: 4). Menyatakan bahwa"Membaca intensif yaitu cara membaca secara seksama terhadap rincian suatu teks atau bacaan." Dengan cara mengarahkan siswa untuk mencari jawaban dari pertanyaan yang telah dibuat sebelumnya sehingga akan lebih efektif daripada membaca biasa. Karena siswa akan lebih teliti dalam memahami setiap detil dalam bacaan. 
4) Reflect yakni pada saat membaca siswa tidak hanya mengingat dan menghafal isi bacaannamun siswa diharapkan sampai memahami isi bacaan, yang didukung oleh kemampuan membaca dan pengetahuan yang dimilikinya. Pada tahap ini siswa harus sudah dapat menemukan dan menuliskan kalimat utama dari teks yang dibacanya.

5) Recite yakni pada tahapan ini siswa diminta mengingat kembali isi bacaan dengan cara menanyakan dan menjawab pertanyaan-pertanyaan yang dibuat, dan dituangkan dalam bentuk catatan singkat. Kegiatan tersebut sependapat dengan pendapat Sumaryo (2004: 9) "Membuat catatan singkat ketika membaca merupakan kegiatan yang dianjurkan bahkan merupakan langkah tersendiri dalam metode membaca yang dikemukakan oleh mereka yang sering membaca." Membuat catatan akan meningkatkan mutu dalam membaca. Karena akan menjadi giat dalam membaca yang kemudian akan berperan secara aktif dalam proses belajar. Menurut Sumaryo (2004:10). "Bentuk catatan singkat dapat berupa tanya jawab, ringkasan dan garis besar" Membuat catatan singkat dalam tahapan ini dengan cara membuat ringkasan dengan menggunakan kalimat utama bacaan yang telah ditemukan sebelumnya sebagai inti dari ringkasan yang dibuat.

6) Review yakni siswa membaca ringkasan yang telah dibuat, mengulang kembali seluruh isi bacaan bila perlu dan sekali lagi menjawab pertanyanpertanyaan yang diajukan jika belum puas akan ringkasan bacaan yang dibuat.

Adapun langkah-langkah Pembelajaran membaca dengan PQR4 dilaksanakan dalam enam tahapan yitu: 1. membaca sekilas; 2 membuat pertanyaan; 3 . membaca dalam hati; 4. Merefleksi; 5. menceritakan kembali; dan 6 meninjau ulang wacana.

\section{METODE PENELITIAN}

\section{A. Metode Penelitian}

Penelitian ini menggunakan pendekatan kualitatif dengan metode penelitian tindakan kelas atau dikenal dengan Classroom action research. Adapun 
Kasbolah (1999: 15) mengemukakan bahwa: "penelitian tindakan kelas adalah penelitian tindakan dalam bidang pendidikan yang dilaksanakan dalam kawasan kelas dengan tujuan untuk memperbaiki atau meningkatkan kualitas pembelajaran”. Desain model Kemmis pada Kasihani Kasbolah (1999: 113) mengutarakan bahwa "PTK menggunakan sistem spiral refleksi diri yang dimulai dengan perencanaan (plan), tindakan(action), observasi (pengamatan), dan refleksi.

Penelitian ini memiliki langkah siklus meliputi: 1.Tahap Perencanaan Tindakan (plan) meliputi: rencana tindakan (termasuk revisi) dengan langkahlangkhnya yaitu: a) peneliti mengadakan penelitian awal mengungkap permasalahan pembelajaran; b) membuat RPP; c) menyiapkan media pembelajaran; d) menyusun instrumen penelitian antara lain: soal tes hasil belajar, lembar observasi, wawancara, dan catatan lapangan; 2. Tahap Pelaksanaan Tindakan yakni melaksanakan sesuai yang telah direncanakan; 3. Tahap Observasi yakni dilakukan selama kegiatan belajar mengajar dengan mengamati aktivitas guru dan aktivitas siswa; 4. Tahap Analisis dan Refleksi yakni data yang diperoleh dari data penilaian hasil belajar, observasi, wawancara dan catatan lapangan dikumpulkan dan dianalisis untuk dijadikan penyusunan program selanjutnya.

\section{B. Subjek Penelitian}

PTK ini dilaksanakan di SDN Pengampon II dengan subjek penelitian ini yaitu siswa kelas IV tahun ajaran 2014/2015 dengan jumlah siswa 26 orang, terdiri atas 15 siswa laki-laki dan 11 siswa perempuan.

\section{Instrumen penelitian}

Instrumen yang digunakan dalam penelitian ini meliputi :1 . Tes Hasil Belajar; 2) Observasi ; 3) Wawancara; 4) Catatan Lapangan

\section{Teknik Pengumpulan Data}

Teknik pengumpulan data dalam penelitian ini adalah dengan teknik tes dan teknik non tes. Teknik tes berupa tes hasil belajar matematika sedangkan teknik non tes berupa observasi, catatan lapangan dan dokumentasi. Data yang 
dikaji oleh peneliti adalah data pelaksanaan tindakan dan data hasil belajar. Pada data pelaksanaan tindakan bersifat deskripsi pelaksanaan pembelajaran.

\section{E. Analisis Data}

Teknik analisis data merupakan prosedur penelitian yang digunakan untuk proses agar data mempunyai makna untuk menjawab masalah dalam penelitian. Data yang sudah dikumpulkan melalui alat pengumpulan data, selanjutnya diolah dan dianalisis secara bertahap melalui tahapan sebagai berikut : (1) Statistik Deskriptif dilakukan dengan mengolah data awal untuk mencari ratarata. (2). Menprosentasikan kelompok siswa yang sudah tuntas dalam belajar dan kelompok siswa yang belum tuntas dalam belajar KKM (Kriteria Ketuntasan Minimal)/ batas tuntas belajar yaitu nilai 70 (kategori cukup) dalam skala 100, menggunakan PAP. Syamsudin, Abin (2002.249) mengemukan bahwa : Criterion referenced evaluation $(\mathrm{PAP}=$ Penilaian Acuan Patokan) merupakan cara mempertimbangkan taraf keberhasilan siswa dengan membandingkan prestasi yang dicapainya dengan kriteria yang yang telah ditetapkan terlebih dahulu.

\section{HASIL PENELITIAN DAN PEMBAHASAN}

Hasil penelitian dengan metode PQR4 pada mata pelajaran Bahasa Indonesia pada asfek pemahaman membaca pada siswa kelas IV SDN Pengampon II dengan Standar Kompetensi: Membaca Memahami teks melalui membaca intensif, membaca nyaring, dan membaca pantun; Kompetensi Dasar: Menemukan kalimat utama pada tiap paragraf melalui membaca intensif, Indikator dalam pembelajaran kemampuan pemahaman membaca yakni menentukan kalimat utama, membuat teks ringkasan dengan kalimat yang runtut, dan menjelaskan isi teks secara tertulis dengan kalimat sendiri secara runtut. Materi pokok adalah membaca cerita anak yang berjudul "Komedi Putar". Adapun langkah-langkah yang harus diperhatikan dan dilakukan oleh siswa dalam pembelajaran dengan metode PQR4.

Adapun tahap metode PQR4 pada setiap siklus dalam pembelajaran yaitu: 1. Tahap Preview ( membaca awal), siswa membaca teks bacaan selintas untuk 
menemukan ide pokok dari bacaan; 2. Tahap Question ( membuat pertanyaan dan jawaban), siswa membuat pertanyaan dan jawaban yang berkaitan dengan isi dari bacaan. Siswa mengajukan pertanyaan dan jawaban sesuai bacaan bersama teman sebangkunya. Siswa ada yang mengajukan pertanyaan dan ada yang menjawab pertanyaan tersebut. Dan menuliskan pertanyaan yang diajukan.; 3. Tahap Read atau membaca intensif. Siswa membaca dalam hati teks bacaan secara seksama, dengan arahan harus dapat menemukan jawaban dari pertanyaan yang telah diajukan sebelumnya. Siswa membahas hasil jawaban yang tepat dari pertanyaan yang telah diajukan sebelumya, dengan bimbingan guru; 4. Tahap Reflect atau memahami, siswa diharapakan dapat memahami isi bacaan dengan menentukan kalimat utama dari tiap paragraf, dengan pengetahuan yang diketahuinya dalam menentukan kalimat utama. Siswa mengerjakan yang disuruh guru menentukan kalimat utama tiap paragraf.Sedangkan guru berkeliling melihat pekerjaan siswa dan memberikan arahan bila ada siswa yang kurang mengerti.Setelah Semua siswa selesai mengerjakan tugas, siswa membahas pekerjaannya dengan bimbingan guru; 5 . Tahap Recite yakni pada tahapan ini siswa diminta mengingat kembali isi bacaan dengan cara menanyakan dan menjawab pertanyaan-pertanyaan yang dibuat, dan dituangkan dalam bentuk catatan singkat; 6. Tahap Review yakni siswa membaca ringkasan yang telah dibuat, mengulang kembali seluruh isi bacaan bila perlu dan sekali lagi menjawab pertanyan-pertanyaan yang diajukan jika belum puas akan ringkasan bacaan yang dibuat.

\section{Pembahasan Siklus 1}

Pelaksanaan penelitian siklus I dengan topic 'Permainan' difokuskan pada kegiatan membaca teks bacaan yang berjudul 'Komidi Putar'. Berdasarkan analisis, dapat diketahui bahwa pengetahuan awal siswa tentang topic yang akan dibahas cukup banyak dan beragam, namun dalam menjawab pertanyaan dari guru siswa masih melakukannya secara serempak, karena guru tidak memberikan pengarahan terlebih dahulu. Dalam membuat pertanyaan pun siswa masih mengalami kesulitan karena guru tidak memberikan pengetahuan bagaimana menemukan ide pokok dari suatu teks bacaan. Waktu 
yang dibutuhkan guru pada siklus 1 tidak cukup sehingga guru perlu mengadakan evaluasi lagi pada siklus selanjutnya.

Berdasarkan hasil pelaksanaan tindakan siklus I, diperoleh beberapa temuan penting sebagai evaluasi terhadap penerapan rencana pembelajaran yang telah disusun sebelumnya yakni skemata siswa belum terbuka sehingga ketika memulai pada tahap kegiatan selanjutnya pikiran atau pengetahuan awal siswa kurang membantu siswa dalam memahami bacaan. Karena menurut Djuanda (2008: 128)“ Seseorang yang sedang memahami sebuah bacaan, pada dasarnya sedang menginteraksikan informasi baru dari bacaan dengan pengetahuan yang tersimpan dalam memorinya." Dengan demikian diperlukan isi bacaan yang diketahui oleh siswa, atau isi bacaan tersebut tidak asing bagi siswa. Karena Cara membaca dalam hati yang dilakukan siswa belum tepat. Masih banyak siswa yang pada saat membaca intensif dalam hati membaca dengan suara yang nyaring. Selain hal tersebut merupakan cara yang salah ketika membaca dalam hati, namun suara-suara yang keluar dan terdengar akan mengganggu konsentrasi yang lainnya dalm membaca. Pada setiap kegiatan kemandirian kesungguhan dan keaktifan siswa belum sesuai dengan yang diharapkan. Pada aspek kemandirian siswa selalu bergantung pada bantuan teman atau guru. Pada aspek kesungguhan, siswa kurang memperhatikan penjelsan guru sehingga pada setiap pelaksanan kegiatan siswa selalu meminta pada guru untuk menjelaskan kembali apa yang disuruhnya.

\section{Pembahasan Siklus II}

Pelaksanaan siklus kedua dengan topik 'Lingkungan'difokuskan pada kegiatan membaca teks bacaan yang berjudul 'Bahaya Sampah'. Berdasarkan analisis tindakan kedua guru memberikan lima pertanyaan sehingga siswa tidak membuat pertanyaan. Waktu yang dibutuhkan tidak kurang seperti siklus I karena waktu yang diperlukan cukup efisien. Guru pada siklus II ini telah memberitahukan bagaimana cara menemukan ide pokok dari teks bacaan. Pada saat proses membaca siswa sudah melakukan kegiatan dengan baik hanya ada beberapa siswa saja yang masih belum mampu memahami. Pada saat membuat intisari siswa masih mengalami kesulitan karena pada saat menjawab 
pertanyaan kebanyakan siswa menjawab tidak dengan kalimat yang benar sehingga pada saat kebanyakan siswa menjawab tidak dengan kalimat yang benar sehingga pada saat merangkai kata-kata untuk membuat intisari masih menemukan kesulitan. Pada saat menjawab pertanyaan jawaban yang dikemukakan masih jauh dari sempurna siswa masih menjawab seadanya tanpa ditambah dengan kata-kata sendiri.

\section{Pembahasan Siklus III}

Pada pelaksanaan siklus III ketiga siswa sudah tidak kaku lagi dan berani mengemukakan pendapat dan menjawab pertanyaan yang diberikan guru dan siswa sudah mampu membuat pertanyaan dengan baik dan dalam membuat intisari siswa sudah tidak menemukan kesulitan lagi.Sehingga dapat dikatakan peneliti sudah berhasil menggunakan strategi belajar PQR4 dalam membaca pemahaman. Adapun kemampuan membaca pada siswa kelas IV SDN Pengampon II pada setiap siklus tersaji pada tabel berikut ini.

Tabel Rekapitulasi Kemampuan Membaca Pemahaman Siklus I sampai Siklus III

\begin{tabular}{|l|c|c|c|c|c|c|c|c|c|c|}
\hline Siklus & \multicolumn{3}{|c|}{$\begin{array}{c}\text { Kemampuan } \\
\text { siswa membuat } \\
\text { kalimat utama }\end{array}$} & \multicolumn{3}{|c|}{$\begin{array}{c}\text { Kemampuan siswa } \\
\text { dalam membuat teks } \\
\text { ringkasan dengan } \\
\text { kalimat yang runtut }\end{array}$} & \multicolumn{2}{c|}{$\begin{array}{c}\text { kemampuan } \\
\text { menjelaskan isi teks } \\
\text { secara tertulis dengan } \\
\text { kalimat sendiri secara } \\
\text { runtut }\end{array}$} & Rata-Rata \\
\hline & $\mathrm{K}$ & $\mathrm{C}$ & $\mathrm{B}$ & $\mathrm{K}$ & $\mathrm{C}$ & $\mathrm{B}$ & $\mathrm{K}$ & $\mathrm{C}$ & $\mathrm{B}$ & \\
\hline $\begin{array}{l}\text { Data } \\
\text { Awal }\end{array}$ & 12 & 10 & 4 & 16 & 8 & 2 & 14 & 9 & 3 & 63,20 \\
\hline I & 8 & 12 & 6 & 10 & 12 & 4 & 6 & 14 & 4 & 73,80 \\
\hline II & 3 & 13 & 10 & 5 & 17 & 6 & 2 & 18 & 6 & 77,60 \\
\hline III & & 11 & 15 & & 9 & 17 & & 13 & 13 & 83,40 \\
\hline
\end{tabular}

Dari data pada tabel diatas menunjukan bahwa dari 26 siswa pada tingkat kemampuan menentukan kalimat utama pada siklus I kategori K (kurang ) yaitu 8 Siswa (31\%), siklus II kategori K (kurang) 3 siswa (12\%),dan siklus III kategori K (kurang) tidak tampak. Sedangkan kategori Cukup siklus I yaitu 12 siswa (46\%), siklus II yaitu 13 siswa ( $50 \%$ ) dan siklus III yaitu 11 siswa (42\%). Kategori Baik pada siklus I yaitu 6 siswa ( $23 \%$ ) Siklus II yaitu 10 siswa ( $38 \%$ ) dan silus III yaitu 15 siswa (58\%) 
Pada tingkat kemampuan siswa dalam membuat teks ringkasan dengan kalimat yang runtut diperoleh siklus I kategori K (kurang) yaitu 10 Siswa (38 $\%$ ), siklus II kategori K (kurang) 5 siswa (19 \%),dan siklus III kategori K (kurang) tidak tampak. Sedangkan kategori cukup silus I yaitu 12 siswa ( 46 $\%$ ), siklus II yaitu 17 (65 \%) dan siklus III yaitu 9 siswa (35\%). Pada kategori B (Baik) yaitu silus I 4 siswa (15\%), siklus II 6 siswa (23\%) dan siklus III yaitu 17 siswa $(65 \%)$

Pada tingkat kemampuan menjelaskan isi teks secara tertulis dengan kalimat sendiri secara runtut diperoleh siklus I kategori K (kurang) yaitu 6 Siswa (23\%), siklus II kategori K (kurang) 2 siswa (8 \%),dan siklus III kategori K (kurang) tidak tampak. Sedangkan kategori cukup silus I yaitu 14 siswa ( $54 \%$ ), siklus II yaitu 18 (69 \%) dan siklus III yaitu 13 siswa (50\%). Pada kategori B (Baik) yaitu silus I 4 siswa (15\%), siklus II 6 siswa (23\%) dan siklus III yaitu 13 siswa $(50 \%)$.

Dari data nilai rata-rata pada setiap siklus mengalami peningkatan yakni pada siklus I nilai rata rata yaitu 73,80 dan pada siklus II niali rata-rata yaitu 77,60 dan pada siklus III nilai rata-rata yaitu 83,40. Dari hasil analisis ada peningkatan pada setiap siklus. Paparan hasil penemuan penelitian di atas membuktikan bahwa penggunaan Metode PQ4R dapat meningkatkan kemampuan membaca pemahaman siswa Kelas IV SD Negeri Pengampon II.. Dengan demikian maka hipotesis yang dibuat peneliti terbukti benar.

\section{Sintesis dan Konfirmasi}

Langkah- langkah pembelajaran dengan metode PQR4 yang dikemukakan oleh Thomas dan Robinson (Trianto,2007) yaitu membaca sekilas, membuat pertanyaan yang sesuai dengan topik bacaan dengan menggunakan kata menggunakan kata apa, siapa, mengapa bagaimana, dan sebagainya, membaca kembali untuk menemukan jawaban dari pertanyaan yang telah dibuatnya, membaca kembali untuk memperoleh informasi dari bacaan, membuat intisari dari bacaan yang diambil dari informasi yang didapatkan,dan membacakan catatan singkat (intisari). 
Berdasarkan hasil tes awal kemampuan membaca pemahaman dengan indikator siswa dapat menentukan kalimat utama, siswa membuat ringkasan dan siswa dapat menjelaskan bacaan dengan kalimatnya sendiri secara runtut dengan benar. Diperoleh data bahwa tingkat kemampuan siswa dalam membaca pemahaman sebelum dilakukan tindakan dengan penerapan metode PQR4 mencapai 63,20. Setelah dilaksanakan tindakan siklus I diperoleh 73,80, siklus II yaitu 77,60 dan siklus III yaitu 83,40. Hasil penelitian yang diperoleh dari temuan-temuan di lapangan, dengan penerapan metode PQ4R dapat meningkatkan kemampuan siswa dalam membaca pemahaman.

\section{KESIMPULAN}

Berdasarkan hasil penelitian tindakan kelas pada siswa kelas IV SDN Pengampon II dapat menarik kesimpulan yaitu : Metode PQ4R dapat meningkatkan kemampuan membaca pemahaman pada siswa kelas IV SDN Pengampon II di dasari oleh data nilai rata-rata pada setiap siklus mengalami peningkatan yakni pada siklus I nilai rata rata yaitu 73,80 dan pada siklus II niali rata-rata yaitu 77,60 dan pada siklus III nilai rata-rata yaitu 83,40.

Penerapan metode PQR4 di Kelas IV SDN Pengampon II untuk meningkatkan pemahaman membaca memiliki beberapa tahap yaitu: Tahap Preview (membaca awal), siswa membaca teks bacaan selintas untuk menemukan ide pokok dari bacaan; Tahap Question ( membuat pertanyaan dan jawaban), Tahap Read (membaca intensif). Siswa membaca dalam hati teks bacaan secara seksama, Tahap Reflect (memahami), siswa diharapakan dapat memahami isi bacaan dengan menentukan kalimat utama dari tiap paragraph; Tahap Recite yakni siswa diminta mengingat kembali isi bacaan dengan cara menanyakan dan menjawab pertanyaan-pertanyaan yang dibuat, dan dituangkan dalam bentuk catatan singkat. 


\section{DAFTAR PUSTAKA}

Abidin,Yunus.2010. Membaca! Bandung:Rizki Press

Akhadiah. 1992/1993. Bahasa Indonesia I. Jakarta: Depdikbud.

Arikunto, Suharsimi. 2002. Prosedur Penelitian suatu Pendekatan Praktek. Jakarta : Rineka Cipta

BNSP. 2007. Standar Kompetensi dan Kompetensi Dasar Kelas IV. Jakarta.Depdiknas

Dahar, Retno Willis. (1996) Teori-teori Belajar. Jakarta : Erlangga

Depdiknas. 2007. Kurikulum Tingkat Satuan Pendidikan Bahasa Indonesia Kelas $V$. Jakarta: Balai Pustaka

Djuanda, Dadan. 2008. Pembelajaran Keterampilan Berbahasa Indonesia di Sekolah Dasar. Bandung: Pustaka Latifah.

Haryadi. 1996/1997. Peningkatan Keterampilan Berbahasa Indonesia. Yogyakarta: Depdikbud.

Muchlisoh, dkk 1992. Pendidikan Bahasa Indonesia. Jakarta : Depdikbud

Moleong, Lexy J. 2000. Metodologgi Penelitian Kualitatif. Bandung: Remaja Rosdakarya.

Rahim, Farida. 2005. Pengajaran Membaca di Sekolah Dasar. Jakarta: Bumi Aksara.

Soedarso,. 2006. Speed Reading system Membaca Cepat dan Efektif. Jakarta: Gramedia Pustaka Utama.

Sumaryo. 2004. Kemampuan Berbahasa dan Bersastra Indonesia untuk SMA kelas X. Semarang: Aneka

Sugiyono. (2007). Metode Penelitian Pendekatan Kuantitatif, Kualitatif, dan $R \& D$. Bandung: Alfabeta

Subagyo. 2006. Bahasa dan Sastra Indonesia. Jakarta: Bumi Aksara

Tarigan, Djago. 1990. Pendidikan Bahasa Indonesia I. Jakarta: Depdikbud 
Trianto. 2007. Model-model Pembelajaran Inovatif Berorientasi Konstruktivistik. Jakarta: Prestasi Pustaka.

Undang-Undang Nomor 20 Tahun 2003. Sistem Pendidikan Nasional. Jakarta. Depdiknas

UU sisdiknas 2003. Jakarta: Depdiknas.

Wiriaatmadja, Rochiati. (2005). Metode Penelitian Tindakan Kelas untuk Meningkatkan Kinerja Guru dan Dosen. Bandung: Rodakarya

Tim Penyusun Kamus. Pusat Bahasa 2005. Kamus Besar Bahasa Indonesia. Jakarta: Balai Pusaka 